\section{VOLATILITÁSI TŐKEPUFFER A SZOLVENCIA II-ES TŐKEKÖVETELMÉNYEK MEGSÉRTÉSÉNEK KIVÉDÉSÉRE}

Zubor Zoltán (Magyar Nemzeti Bank, vezető aktuárius) zuborz@mnb.hu

Jelen tanulmány a Hitelintézeti Szemle, 15. évf., 1. számában megjelent tanulmány változatlan tartalommal való közlése.

\section{ÖSSZEFOGLALÓ}

A Szolvencia II-es szabályozás úgy ír elő folyamatos tőkemegfelelést, hogy a biztosítók csak évente határozzák meg megbízható módon a tőkemegfelelésüket. A volatilitási tőkepuffer ${ }^{1}$ (VTP) azt hivatott garantálni, hogy a piaci értékelés miatti nagyobb volatilitás ellenére - adott a megbízhatósági szinten - a biztosítók szavatoló tőkéje folyamatosan elérje a tőkeszükséglet szintjét. Jelen cikk a problémát azon valószínűségeloszlás a megbízhatósági szinthez tartozó kvantilisének keresésére (VaR $)$ vezeti vissza, melynek 99,5 százalékos kvantilise a Szolvencia II-es szabályozásban megjelenő szavatolótőke-szükséglet (SCR), és így a VTP az SCR százalékában fejezhető ki. Az eloszlásra vonatkozó feltevések nélkül a VTP-arányra bármilyen érték adódhat, de már természetes feltételezések mellett is viszonylag szűk sávba szorítható. A nevezetes eloszláscsoportok vizsgálata egyrészt tovább szűkíti a szóba jöhető értékeket, másrészt rámutat, hogy a vastagabb farkú eloszlások esetén (amikor jelentősebb, extrém veszteségek is gyakrabban fordulhatnak elö), illetve jobbra ferde eloszlások esetén (amikor a veszteség valószínűsége ugyan kisebb a nyereségénél, de a mértéke várhatóan nagyobb) kisebb VTP-arány adódik.

\section{SUMMARY}

The Solvency II regulation prescribes continuous capital adequacy, despite the fact that insurance companies only determine their capital adequacy in a reliable manner once a year . The volatility capital buffer ${ }^{2}(\mathrm{VCB})$ is meant to guarantee that, despite the higher volatility arising from the market valuation, at a given a confidence level the solvency capital of insurers meets the capital requirement on a continuous basis. This paper reduces the problem to the search of the probability distribution quantile belonging to the a confidence level $\left(\mathrm{VaR}_{\alpha}\right)$, the 99.5 per cent quantile of which is the solvency capital requirement (SCR) specified in the Solvency II Capital Regulation, and thus the VCB can be expressed as a percentage of the SCR. Without any assumptions related to the distribution, any value may be obtained for the VCB ratio, but it can be squeezed into a relatively narrow band even under natural assumptions. On the one hand, the analysis of these distribution groups may further narrow the possible values, and on the other hand it points out that in the case of fatter-tailed distributions (when major, extreme losses may also occur more frequently) and positive skewness (when the probability of the loss is smaller than that of the profit, but the value thereof is expected to be higher), we obtain a lower VCB ratio.
Kulcsszavak: Szolvencia II, volatilitás, tőkepuffer, veszteségeloszlás, kvantilis, megbízhatósági szint

Keywords: Solvency II, volatility, capital buffer, loss distribution, quantile, confidence level

\section{JEL: C13, C46, G22}

DOI: $10.18530 / \mathrm{BK} .2016 .3 .12$

http://dx.doi.org/1018530/BK.2016.3.12

\section{Bevezetés}

A 2016. január 1-jével hatályba lépett Szolvencia II rendszer két legfontosabb mennyiségi eleme a piaci értékelésre történő áttérés, illetve a biztosító valamennyi kockázatát lefedő tőkeszükséglet. A biztosítási kötelezettségeknek nincs piacuk, ezért a piacon megfigyelhető áruk sincs. Az új rezsim azt az értéket modellezi, amely mellett a kötelezettségeket egy másik biztosító átvállalná. A szavatolótőke-szükséglet esetén pedig azt az értéket kell meghatározni, amely esetén legfeljebb 0,5 százalék annak a valószínűsége, hogy a biztosító szavatoló tőkéje egy év alatt ennél nagyobb mértékben csökken.

A piaci értékelésre történő áttérés magában hordozza a szavatoló tőke, illetve tőkemegfelelés nagyobb mértékű rövid távú ingadozását (EIOPA 2011; EIOPA 2013). A tőkemegfelelés, illetve ezen keresztül a biztosítók pénzügyi pozíciójának rövid távú magas változékonysága nincs összhangban az üzlet jellemzően hosszú távú jellegével (Insurance Europe 2013). A fiktív volatilitás (artificial volatility) kiküszöbölésére több elképzelés is született, amelyeket az Európai Biztositási- és Foglalkoztatóinyugdíj-hatóság (EIOPA) az LTGA ${ }^{3}$ hatástanulmányban tesztelt 2013-ban (EIOPA 2013). A jelenlegi szabályozásban a fiktív volatilitás kisimítására a volatilitási kiigazítás, az illeszkedési kiigazítás, illetve a kezdeti időszakban az átmeneti intézkedések szolgálnak (LTG-intézkedések).

Az EIOPA 2014. évi stressztesztje alapján az LTG-intézkedések hatása felemás. Az egyes elemek ugyan jelentős hatást gyakorolhatnak a tőkemegfelelésre ${ }^{4}$, azonban a lehetőséggel csak kevesen éltek, élhettek: a volatilitási kiigazítást a résztvevők 31 százaléka, az illeszkedési kiigazítást 7, a különféle átmeneti rendelkezéseket pedig 2-10 százaléka alkalmazta (EIOPA 2014).

A Szolvencia II-es (S2) tőkemegfelelés nagyobb volatilitása a hazai piacot is érinti (MNB 2015a), amit a hatástanulmányok is alátámasztottak (MNB 2015b; Bora et al. 2015). A legutóbbi öt hatástanulmány ${ }^{5}$ mindegyikében részt vevő 11 biztosító ${ }^{6}$ adatai alapján a Szolvencia l-es tőkemegfelelési mutatóik relatív szórásainak ${ }^{7}$ átlaga 0,179 , míg a Szolvencia II-es ráták esetében 0,260, ami jól mutatja, hogy az új rezsimben a tőkemegfelelés lényegesen volatilisebb. 
A hazai piacon az LTG-intézkedések hatása szerény. A Magyar Nemzeti Bank által 2014-ben végrehajtott mennyiségi hatástanulmány alapján a részt vevő biztosítók ${ }^{8}$ egyike sem alkalmazta, illetve a jövőben sem kívánja alkalmazni az illeszkedési kiigazítást. A volatilitási kiigazítás hatását mindenki bemutatta, de ez mindössze a tőkeszint 4,1 százalékos javulását eredményezte, azaz az LTG-intézkedések a Szolvencia II-es tőkemegfelelés magas, fiktív ingadozását csak kismértékben képesek tompítani, a magas volatilitásból fakadó kockázatokat nem szüntetik meg.

A 138/2009 EK irányelv (a továbbiakban irányelv) 100. cikkelye, valamint (ezzel összhangban) a 88/2014. évi törvény (a továbbiakban Bit.) 99.\$-a föszabályként folyamatos tőkemegfelelést ír elö, miközben az elöírt tőkekövetelményeknek való megfelelést a biztosítóknak csak bizonyos időközönként kell meghatározniuk, illetve bemutatniuk: a szavatolótőke-szükségletet évenként, a szavatoló tőkét negyedévenként. Hogyan lehet garantálni ezt a megfelelést a köztes időszakokban? A szabályozás erre felemás megoldást nyúit. A biztosítónak csak a legutoljára jelentett szavatolótőke-szükségletnek kell megfelelnie, melyet év közben is újra kell számolnia, ha a biztosító kockázati profilja jelentősen megváltozik. A szavatoló tőke alakulását ugyan folyamatosan figyelni kell, illetve negyedévente jelenteni, de teljes részletességű, auditált adatokon történő futtatásra általában csak évente kerül sor, azaz a magas volatilitás miatt könnyen előfordulhat, hogy egy megfelelő, például 120 százalékos tőkeszintű biztosító akár egy éven belül is tőkehiányossá válik, és ezzel megsérti a jogszabályokat.

Amennyiben egy biztosító, illetve a felügyeleti hatóság csökkenteni szeretné egy tőkehiányos állapot kialakulásának kockázatát azon köztes időszakban, amíg a biztosító megbízható módon újra meg nem határozza a tőkehelyzetét, célszerü a tőkekövetelményeknél valamennyivel több tőkét (tőkepuffert) tartani, illetve ezt a biztosítóktól elvárni.

A nagyobb volatilitásból eredő kockázatok tőkepufferrel (volatilitási tőkepuffer) való kezelésére eddig nem találtunk példát, így irodalma sincsen. A témát, illetve magának a volatilitási tőkepuffernek a fogalmát elöször 2014 novemberében Nagy Koppány (MNB) vetette föl a MABISZ konferenciáján. Jelen cikk egyik legfontosabb célja a volatilitási tőkepuffer (VTP) céljának ${ }^{9}$ és pontos tartalmának meghatározása, bevezetése.

A cikk másik fontos célja egy olyan megközelítés bemutatása, amellyel a VTP-t (az SCR mögötti valószínűségeloszláson keresztül - ld. később) vissza lehet vezetni az SCR értékére. Látni fogjuk, hogy a szóban forgó eloszlásra vonatkozó feltevés hiányában a VTP-re bármilyen érték is adódhat, de különféle természetes feltételezések mellett a szóba jöhető puffermértékek kezelhető korlátok közé szoríthatók. Az egyes eloszláscsaládok vizsgálata egyfelől támpontot ad arra, hogy milyen tőkepuffert kell/érdemes tartani, ha a biztosító kockázati profilja az adott eloszláscsaládnak felel meg leginkább. Másfelől arra világít rá hogy kisebb arányú tőkepuffer adódik azon biztosítók esetében, amelyeknél az extrém veszteségek nagyobb eséllyel fordulnak elö ${ }^{10}$, illetve, ahol a várható veszteség mértéke inkább meghaladja a várható nyereség mértékét, azaz a normális eloszlás feltételezése többnyire felső becslést eredményez a VTP értékére.

\section{A volatilitási tőkepuffer célja}

A volatilitási tőkepuffer célja annak a kockázatát csökkenteni, hogy a biztosító tőkehiányos állapotba kerüljön a tőkemegfelelés megbízható számításai és bemutatásai közötti időszakokban.

Egy biztosító tőkemegfelelése több tényező miatt változhat. Ezeket a tényezőket három szempont szerint csoportosíthatjuk:

i. Az állomány szerint: A változás a régi, az előzetes várakozásoknak megfelelően alakult új vagy a várttól jelentősen eltérő állományváltozás miatt következett-e be? Régi, illetve új állományon itt a legutóbbi megbízható tőkemegfelelési jelentés vonatkozási időpontjában már meglévő, illetve azt követően - a következő számításig - szerzett állományt kell érteni, figyelemmel a szerződés határaira is.

ii. Az alapkomponensek szerint: A javulás/romlás a tőkeszükséglet vagy a figyelembe vehető szavatoló tőke változása miatt következett-e be?

iii. A kiváltó ok típusa szerint: A tőkeszint változása külső vagy belső okok miatt következett-e be? Belső tényezőnek kell tekinteni minden olyan történést, amely a biztosítóra vagy a tulajdonosokra vezethető vissza, mint például az egyes mérlegtételek, tőkeelemek, illetve az SCR meghatározására szolgáló modellek, feltételezések, eljárások változtatása, osztalékkifizetés vagy tőkefeltöltés.

A Bit. 268.\$ (1) bekezdése, illetve a 43/2015-ös kormányrendelet (a továbbiakban 43-as rendelet) 27. \$-a alapján a biztosítónak soron kívül újra kell számítania a tőkeszükségletét, ha a kockázati profilja jelentősen megváltozott, például ha az állománya a várttól jelentősen eltérő módon és mértékben változott. Ilyen esetben (a 43-as rendelet 27 . $\$$ (5) bekezdésére ${ }^{11}$ is tekintettel) elvárható, hogy a teljes tőkemegfelelését számolja újra, és jelentse a felügyeleti hatóságnak. Ugyancsak elvárható, hogy a biztosító számolja újra és jelentse tőkemegfelelését, ha olyan új modelleket, feltételezéseket, eljárásokat vezet be, amelyek jelentősen befolyásolják a tőkemegfelelést.

Mindezek alapján a volatilitási tőkepuffernek csak a régi, illetve a várható új állományra kell reflektálni, és csak a szavatoló tőke azon változásából eredő kockázatokat kell tompítani, amelyek a külső tényező változása (környezeti változások) miatt következtek be.

A szavatoló tőke az alapvető és a kiegészítő szavatoló tőke összege. Az alapvető szavatoló tőke pedig az eszközök forrásokat meghaladó részéből (nettó eszközérték) és az alárendelt kölcsöntőkéből áll. Magyarországon a kiegészítő tőke szerepe marginális. Másfelől jól elkülöníthető, illetve nincs kitéve a véletlenszerű ingadozásnak. Ez utóbbi az alárendelt kölcsöntőkére is érvényes, azaz a VTP szempontjából a szavatoló tőkéből mindössze a nettó eszközérték változása az érdekes. 
A tőkehiányos állapot elkerülésekor nem célszerü, illetve többnyire nem is lehet 100 százalékos biztonságra törekedni. A volatilitási tőkepuffer azt a többlettőkét jelenti, ami az adott - a fentiek alapján egyéves - időhorizonton a megcélzott $\alpha$ megbízhatósági szint $(0 \%<\alpha<100 \%)$ mellett véd az alapvető szavatoló tőke ingadozásával szemben, és biztosítja a jogszabályok szerinti folyamatos tőkemegfelelést. Szabatosabb megfogalmazásban $V T P_{\alpha}$ az az érték, amire

$$
P\left(X<V T P_{\alpha}\right)=\alpha,
$$

ahol az $X$ valószínűségi változó az alapvető szavatoló tőke értének adott időtávon belüli, külső tényezők miatt csökkenése a régi és a várhatóan szerzett új biztosítási állomány tekintetében ${ }^{12}$. $V T P$ az $X$ valószínűségi változó $\alpha$ szinthez tartozó kvantilise, vagy a Bit.-ben is használt terminológiával: a kockáztatott értéke

$$
V T P_{\alpha}=\operatorname{VaR}_{\alpha}(X)
$$

Az irányelv 101. cikkének (3) bekezdése fogalmazása szerint „A szavatolótőke-szükségletet úgy kell kalibrálni, hogy minden olyan számszerüsíthető kockázatot figyelembe vegyen, amelynek a biztosító vagy viszontbiztosító ki van téve. Kiterjed a meglévő biztositási állományra és a következő tizenkét hónapban várhatóan szerzett új biztositási állományra. A meglévö biztositási állomány tekintetében csak a nem várt veszteségekre terjed ki. A szavatolótőke-szükséglet a biztosító vagy viszontbiztosító alapvető szavatoló tőkéje egyéves időtávon mért, 99,5 százalékos biztonsági szintű kockáztatott értékének felel meg." Ezen megfogalmazás alapján az egyéves időhorizontú $V T P$ meghatározásában szereplő $X$ valószínűségi változó megegyezik azzal a valószínűségi változóval, amely a szavatolótőke-szükséglet meghatározásában is szerepel, aminek a 99,5 százalékos kvantiliséhez (VaR-jához) tartozó érték az SCR, azaz

$$
V T P_{99,5 \%}=S C R \text {. }
$$

Ezzel a feladatot visszavezettük olyan valószínűségi változó adott megbízhatósági szinthez tartozó kvantilisének a keresésére, aminek 99,5 százalékos kvantilisét ismerjük (legalábbis elvben - ld. később). Hogy pontosan lássuk, hogy ez a megközelítés mit jelent valójában, és az így kapott VTP milyen kockázatokat kezel, tisztázni kell, hogy miféle $X$ valószínűségi változónak is a 99,5 százalékos kockáztatott értéke (legalábbis elvben) az SCR.

A S2-es szabályozás alapján az $X$ a régi és a következő 12 hónapban várhatóan szerzett állományon elszenvedett veszteséget jelenti. A biztosítástechnikai tartalékok képzésénél figyelembe kell venni (a maga valószínűségével) minden lehetséges jövőbeni pénzáramot, amely a (szerződés határain belül) a régi állományból ered. Ez alapján $X$ a nem várt veszteséget jelenti a régi állomány tekintetében. Ezt az irányelv 101. cikkének (3) bekezdése is megerősíti. A következő 12 hónapban szerzett állomány tekintetében azonban ilyen kitétel nem található a jogszabályokban, így itt a várható veszteséget (a biztosítók több- sége esetén valójában nyereséget) is figyelembe kell venni. Ennek azonban nincs nyoma a standard formulában, ezért a továbbiakban feltételezem, hogy az új állomány tekintetében is a nem várt veszteségekre nyújt fedezetet a szavatolótőke-szükséglet, azaz hogy az SCR (standard formula segítségével történő) meghatározása alapjául szolgáló veszteség (az $X$ valószínűségi változó) várható értéke nulla.

Kérdés, hogy figyelembe szeretnénk-e venni az új állomány várható nyereségességét, és ha igen, akkor hogyan. A megfogalmazott célok alapján a volatilitási tőkepuffernek csak a nem várt részre kell reflektálni, azonban az alkalmazás során szem elött kell tartani, hogy a várható eredmény egyáltalán nem esetleges. Például egy lakásbiztosítási szerződést tipikusan úgy kell tekinteni, mintha az a következő biztosítási évfordulón megszűnne. A szerződések többsége azonban automatikusan megúításra kerül (ami a szerződés határainak meghatározása alapján új szerződésnek minősül), így egy nyereséges állomány esetén az elkövetkező 12 hónapban szerzett új állomány várhatóan szintén nyereséges lesz.

A továbbiakban a nem várt veszteség képezi a volatilitási tőkepuffer alapját, azaz $V T P=V a R_{\alpha}(X)$, ahol $X$ az alapvető szavatoló tőkének a környezeti változások miatti nem várt csökkenése a régi és a következő 12 hónapban várhatóan szerzett új biztosítási állomány tekintetében, az SCR standard formulájának elvi meghatározásához hasonlóan.

Tehát egy olyan valószínűségi változó $\alpha$ kvantilisét keressük (VTP), aminek a 99,5 százalékos kvantilisét ismerjük (SCR). De vajon a standard formulával meghatározott SCR valóban megegyezik az adott biztosító tényleges $X$ valószínűségi változójának 99,5 százalékos kvantilisével? Ehhez az alábbiak mindegyikének teljesülni kellene:

(i) a standard formula jól kalibrált,

(ii) az adott biztosító kockázati profilját pontosan írja le a standard formula,

(iii) a biztosító pontosan a standard formulának megfelelően, valós, megbízható adatokon számolta a tőkeszükségletét.

Ezek közül az első kettő biztosan nem teljesül: gondoljunk csak a 0,25 többszöröseiként meghatározott korrelációs együtthatókra vagy a megyén belül azonosan meghatározott árvízkockázati faktorokra. Azt lehet, és talán érdemes is vitatni, hogy a standard formula mennyire méri jól a kockázatokat, de nem a volatilitási tőkepuffer kapcsán, ezért a továbbiakban feltételezem, hogy a biztosító által kiszámolt és jelentett SCR éppen annak a valószínűségi változónak a 99,5 százalékos kvantilise, aminek $\alpha$ kvantilisét keressük.

A S2 rezsim kétszintű tőkekövetelményt ír elő. A többnyire alacsonyabb mértékü13 rűen számítható, negyedévente meghatározandó minimális tőkeszükséglet $(M C R)$ megsértése lényegesen szigorúbb felügyeleti intézkedést von maga után. A szigorúbb (magasabb) szavatolótőke-szükségletet (SCR) egy összetett, a szóba jöhető kockázatok mindegyikére reflektálni kívánó modell segítségével évente kell meghatározni. Ezt a kétszintű rendszert érdemes lekövetni a volatilitási tőkepufferrel is, különböző megbízhatósági szintekkel: az MCR esetében kellene egy magasabb szintet megcélozni. 


\section{A volatilitási tőkepuffer kiszámításának lehetséges megközelítései}

\subsection{A teljes nem várt veszteség eloszlása alapján}

Az 1. fejezetben megfogalmazottak alapján $V T P=\operatorname{Va} R_{\alpha}(X)$, ahol $X-$ az alapvető szavatoló tőke nem várt csökkenése - ugyanaz a valószínűségi változó, aminek 99,5 százalékos kvantilise az $S C R$

Ha ismernénk az $X$ eloszlását, akkor VTP könnyen meghatározható lenne. A nem várt veszteség azonban sokféle sokkhatás eredőjeként következik be, bonyolult kölcsönhatások, függési viszonyok mellett, ezért az eloszlás pontos meghatározása nem lehetséges. Ráadásul az eltérő káreloszlású szerződésekkel, eltérő viszontbiztosítási fedezetekkel, eltérő eszközportfólióval stb. rendelkező biztosítók esetén a nem várt veszteség eloszlásának jellemzői alapvetően eltérhetnek egymástól.

Az eloszlás típusára (az eloszláscsaládra) vonatkozó különféle feltételezésekkel élve, a szükséges paraméterek becslésével lehet közelítéseket végezni a tőkepufferre. Ebben felhasználhatjuk, hogy az SCR ugyanezen eloszlás 99,5 százalékos szinthez tartozó kockáztatott értéke egyéves időhorizonton.

$\mathrm{Az} S C R=V_{a} R_{99,5 \%}$ alapvetésből kiindulva az eloszlásra tett általánosabb feltételezések alapján is lehet alsó és felső becsléseket végezni a $V T P$-re, ami segítheti a különféle eloszláscsaládokra tett feltételezésekkel adódó eredmények megítélését.

\subsection{A nem várt veszteség moduláris felbontása alapján}

Látni fogjuk, hogy a teljes nem várt veszteség alapján keresett tőkepuffer mértéke nagyban függ a veszteség eloszlásától. Az egyes biztositók eltérő üzleti modelljeiből adódóan ez az eloszlás markánsan eltérő is lehet, és ez az eltérés a VTP becslését is jelentősen befolyásolhatja, illetve találhatók olyan fiktív üzleti modellek, amelyek esetén az eltérő eloszlások szélsőségesen eltérő tőkepuffert generálnak (ld. 4.2.1. fejezet).

Ezt a problémát - jelentős többletmunkával - megpróbálhatjuk úgy orvosolni, hogy a veszteségfüggvényt az SCR standard formulája moduljainak megfelelöen komponenseire bontjuk, az egyes komponensekre meghatározzuk a megfelelő volatilitási tőkepuffer részt, és a megfelelő korrelációk alkalmazásával aggregáljuk.

Ettől a módszertől csak akkor várhatunk pontosabb és megbízhatóbb eredményt, ha ismerjük az egyes modulokhoz tartozó nem várt veszteség eloszlását. Ha csak a nem-életbiztosítási katasztrófakockázati modult vesszük alapul, akkor a veszteség eloszlása alapvetően eltér attól függően, hogy arányos vagy nem arányos viszontbiztosítási fedezettel rendelkezik-e az adott biztosító.

Tehát az egyes modulok esetében is előfordulhat a fejezet első felében tárgyalt probléma, amit a moduláris megközelítéssel kívántunk megoldani. És bár elképzelhető, hogy az egyes moduloknál megalapozottabban lehet feltételezni a nem várt veszteség eloszlását, és így kisebb hibahatárral tudjuk az egyes modulok esetében a $V T P$-t becsülni, az egyes részeredmények aggregációja nem megoldott. Az SCR standard formulájában ugyan meg vannak adva az aggregáláshoz használandó korrelációk, de azok a 99,5 százalékos megbízhatósági szinthez (a 99,5\%-os VaR-hoz) tartoznak, és semmi sem garantálja, hogy ugyanazon korrelációk alkalmasak a például 75 százalékos megbízhatósági szint esetében. Az eltérő diverzifikációs hatás jelentősen torzíthatja a végeredményt.

Vegyük például a $[-0,5 ; 0,5] X[-0,5 ; 0,5]$-es négyzeten egyenletes kétdimenziós $(X ; Y)$ eloszlás $X$ és $Y$ peremeloszlásait! Ezek a [-0,5; 0,5] intervallumon egyenletes eloszlású, 0 várható értékü, független valószínűségi változók, melyek $\alpha$-hoz tartozó kvantilise $\alpha$-0,5-tel egyezik meg. Könnyen belátható, hogy a $Z=X+Y$ valószínüségi változó megfelelő kvantilise $1-\sqrt{2 \cdot(1-a)}$.

Ha a standard formulának megfelelően a $\sqrt{V a R_{X}^{2}+2 \cdot \rho \cdot V a R_{X} \cdot V a R_{Y}+V a R_{Y}^{2}}$ módon szeretnénk a peremeloszlások VaR-ját aggregálni, akkor $\alpha=99,5 \%$ esetén $\rho=0,653$-del kellene az aggregálást elvégezni, míg $\alpha=75 \%$ esetén $\rho=-0,314$-del. A 0,653-del történő aggregálás 55,2 százalékkal felfele torzítaná az eredményt.

Másfelől a pontosabb becslésnél fontosabb, hogy a megcélzandó tőkeszintet alsó és felső korlátok közé lehessen szorítani, azaz meg tudjuk mondani, hogy az adott becslés alsó vagy felső becslés. Kérdéses, hogy a moduláris megközelítéssel nem veszítünk-e többet az aggregálás problematikáján, mint amennyit nyerünk az egyes modulok pontosabb becsülhetőségével. Ez jelenleg nyitott kérdés.

Összegezve: A moduláris megközelítés nem csökkenti jelentősen a becsült volatilitási tőkepuffer megbízhatóságát, viszont a sokféle torzító hatás rontja az elméleti érték és a becslés esetleges diszharmóniájának átláthatóságát, ezért ezt a megközelítést a továbbiakban nem részletezem.

\subsection{Empirikus megközelítés}

A veszteségfüggvény megfelelő kvantilisét a szavatoló tőke vagy a tőkepozíció (tőketöbblet) változására vonatkozó tapasztalati adatok segítségével is becsülhetjük

A tapasztalati VaR használhatóságához viszonylag sok megfigyelt értékre, azaz esetünkben hosszú idősorra van szükség. Például ahhoz, hogy a 90 százalékos szinthez tartozó tapasztalati kvantilis értékét ne automatikusan a legnagyobb érték határozza meg, legalább 15-20 adatra lenne szükségünk, ami 15-20 éves idősort jelent. Ezt a módszert nemcsak azért kell kizárni, mert ilyen hosszú S2-es idősorral nem rendelkezünk, hanem azért is, mert a használhatóság feltétele, hogy a megfigyelési értékek azonos eloszlású valószínűségi változótól származzanak, azaz hogy a biztosító kockázati profilja, illetve a környezet ${ }^{14}$ ne változzon meg. Ezt még rövid időtávon belül sem lehet feltételezni.

A másik lehetőség, hogy feltételezzük, hogy a nem várt veszteség eloszlása valamely eloszláscsaládba tartozik, és a rendelkezésre álló adatokból a feltételezett eloszlás szükséges paramétereit becsüljük meg. Például az eloszlás szórását az empirikus szórás segítségével. A hiányzó paraméterek becslése is csak akkor ad megbízható eredményt, ha kellően sok megfigyelésünk, azaz kellően hosszú idősorunk van. Hosszabb időtávon viszont nem lehet garantálni az eloszlás 
változatlanságát, ami pedig szintén feltétele a módszer alkalmazhatóságának.

További feltétel mindkét esetben, hogy a megfigyelési értékek függetlenek legyenek egymástól. Kérdéses, hogy a nem várt veszteségek évenkénti értékei mennyire tekinthetők függetlennek.

A tapasztalati szóráshoz kapcsolt tőkepuffer logikus választás, hiszen a nem várt veszteségek szórása jellemzi leginkább azt a volatilitást, amivel szemben a VTP védi a biztosítót a tőkeelégtelenségtől. A veszteség eloszlásának (eloszlástípusának) ismerete nélkül azonban nem tudjuk megmondani, hogy például egy 2/3 (tapasztalati) szórásnyi tőkepuffer milyen szintű (valószínűségű) védelmet nyújt. Normális eloszlás esetén 75 százalékosat, de egyéb eloszlások esetén ez lehet túlzottan vagy nem kellően óvatos. A fentiekben említett tényezők (kellően hosszú idősor, az eloszlás és környezet változatlansága, függetlenség) még inkább megkérdőjelezik az így adódó becslés megfelelőségét.

A 4.3. fejezetben annak ellenére bemutatok tapasztalati adatokat, hogy a fentiek alapján azok alapján megfelelő VTP-t nem lehet meghatározni.

\subsection{Időhorizont}

A volatilitási tőkepuffer célja a tőkeelégtelenség elkerülése azon köztes időszakokban, amikor a biztosító nem határozza meg a tőkepozícióját. A minimális tőkeszükségletet és a szavatoló tőkét negyedévente, míg a szavatolótőke-szükségletet évente kell meghatározni. A biztosítóknak csak a legutoljára jelentett tőkeszükségleteknek kell megfelelni, így a tőkeszükségletek esetleges változása ellen a VTP-nek nem kell védelmet nyújtania. Ez azt jelenti, hogy a „köztes időszak” az az időszak, amikor a szavatoló tőkéről nincs információnk, azaz a tőkepuffernek egy negyedéves időhorizonton kell megfelelő szintű védelmet biztosítani. Másfelől a biztosítók sok esetben csak évente végeznek pontos számításokat az egyes eszközök és föleg a kötelezettségek értékének meghatározására, illetve csak évente kell az adataikat auditáltatni, ami megkérdőjelezi a negyedéves értékék megbízhatóságát. A tőkepuffer az elnagyoltabb becslésekből eredő bizonytalanságok kiküszöbölését is célul tűzheti ki, ami fölveti az éves időhorizont szükségességét.

Ha $X_{i}$ jelöli az $i$-edik negyedévben bekövetkező nem várt veszteséget $\left(X=X_{1}+X_{2}+X_{3}+X_{4}\right)$ és ismerjük a $\operatorname{VaR}_{\alpha}(X)$ értékét, akkor bizonyos körülmények között meghatározhatjuk a $\operatorname{VaR}_{\alpha}\left(X_{I}\right)$ értékét is. Például ha a VaRa szórással arányos (pl. normális eloszlás esetében), és feltesszük, hogy az $X_{i}$-k függetlenek és azonos eloszlásúak, akkor

$$
\operatorname{VaR}_{a}\left(X_{1}\right)=\frac{\operatorname{VaR}_{\alpha}(x)}{2}
$$

Azonban általában sem az arányosság, sem a függetlenség, sem az eloszlások azonossága nem teljesül.
Tegyük fel például, hogy egy biztosító kizárólag a hozamgörbe csökkenésére érzékeny. Az első negyedévben bekövetkezett jelentősebb nem várt veszteség azt jelenti, hogy a hozamgörbe jelentősen lesüllyedt. Ekkor viszont a hozamgörbe már nem tud a második negyedévben olyan mértékben tovább csökkenni, hogy még egyszer ilyen mértékű vesztesége keletkezzen. Tehát $X_{1}$ értéke az $X_{2}$ eloszlását is befolyásolja, nemcsak az értékét.

A továbbiakban az egyéves időhorizonthoz tartozó VTP-t keressük.

\section{A volatilitási tőkepuffer becslése}

A feladat egy nulla várható értékű valószínűségi változó $\alpha$ kvantilisének meghatározása a 99,5 százalékos kvantilisének ismeretében. Látni fogjuk, hogy ha nem teszünk föl semmit az X eloszlásáról, akkor a $v t p_{\alpha}=\frac{V T P_{\alpha}}{S R C}$ arányra bármilyen érték is adódhat.

Kézenfekvő abból kiindulni, hogy az X normális eloszlású. Ebben az esetben egyszerűen, a konkrét eloszlás paramétereitől függetlenül megkapjuk a VTP értékeit az $\alpha$ függvényében. Kiindulási, viszonyítási értékként ezt fontolóra is vehetjük, egy biztosító veszteségének eloszlása azonban jelentősen eltérhet a normálistól. Tipikusan ez a helyzet, amikor a biztosító jelentős kockázatokat vagy hosszú kifutású kötelezettségeket vállal, és így nagy veszteség is előfordulhat, míg a nyereség nagysága viszonylag korlátozott (azaz az eloszlás jobbra ferdül ${ }^{15}$ ), illetve amikor nagyobb veszteségek is nem elhanyagolható valószínűséggel fordulhatnak elő („,vastagabb farkú”16 eloszlás). Ezért érdemes megvizsgálni a többi, szóba jöhető eloszláscsaládot is.

A valós veszteségeloszlások legfeljebb jobb-rosszabb közelítéssel tartoznak valamelyik eloszláscsaládba, ezért az eloszlás általánosabb tulajdonságai alapján történő megszorítások vizsgálata is hasznos lehet a gyakorlati alkalmazás szempontjából.

4.1. A veszteség eloszlásának típusára (eloszláscsaládjára) vonatkozó feltételezések alapján

A fejezet célja kettős. Egyfelől betekintést kaphatunk, hogy milyen VTP-értékek adódnának, ha tudnánk, hogy az $X$ valószínűségi változó milyen típusú. Másfelől az eredmények azt mutatják, hogy a jobbra ferdült, illetve vastagabb farkú tulajdonságok csökkentik a tőkepuffer mértékét, azaz a normalitás feltételezésével kapott értékek egyfajta felső becslésként foghatók fel.

A fejezet a nevezetes eloszláscsaládokat az okvetlenül szükségesnél kicsit részletesebben taglalja, hogy azok is el tudják helyezni az adódott értékeket (azok milyen esetben közelíthetik egyes biztosítók veszteségeloszlásait, az eredmény mennyire lehet reális), akik az egyes eloszláscsaládok sajátosságait kevésbé ismerik. 


\subsubsection{Ha feltesszük, hogy $\mathrm{X}$ normális eloszlású}

Ebben az esetben

$V T P_{\alpha}=\Phi^{-1}(\alpha) \cdot \sigma+m$,

ahol $\Phi^{-1}$ a standard normális eloszlás eloszlásfüggvényének inverze, $\sigma$ az $X$ szórása, $m$ az $X$ várható értéke. $E(X)=0$ alapján $m=0$.

Másfelől ( $m=0$-t fölhasználva)

$\operatorname{SCR}=\Phi^{-1}(99,5 \%) \cdot \sigma$, ahonnan

$$
\begin{gathered}
\sigma=\frac{S C R}{\varphi^{-1}(99,5 \%)} \cdot \text { Behelyettesítve: } \\
\qquad T P_{a}=\frac{\varphi^{-1}(\alpha)}{\varphi^{-1}(99,5 \%)} \cdot S C R
\end{gathered}
$$

ami praktikusan $\left(1+v t p_{\alpha}\right)$ - szoros tőkemegfelelési elvárást jelent, ahol

$$
v t p_{\alpha}=\frac{\varphi^{-1}(a)}{\varphi^{-1}(99,5 \%)}
$$

Az így adódó tőkepuffer értéke könnyen meghatározható, az egyes szintekhez tartozó értékeket az 1. táblázatban találjuk. Például 126,2 százalékos tőkemegfelelés esetén a biztosító 75 százalékos valószínűséggel egy év elteltével is megfelel a (régi) tőkeszükségletnek, 90 százalékos megbízhatóság megvalósításához már csaknem 150 százalékos tőkeszint szükséges.

\section{1. táblázat: Volatilitási tőkepuffer az SCR százalékában - normális eloszlás}

\begin{tabular}{|l|rrrrrrrrrr|}
\hline$\alpha$ & $\mathbf{5 0} \%$ & $\mathbf{5 5} \%$ & $\mathbf{6 0} \%$ & $\mathbf{6 5} \%$ & $\mathbf{7 0} \%$ & $\mathbf{7 5} \%$ & $\mathbf{8 0} \%$ & $\mathbf{8 5} \%$ & $\mathbf{9 0} \%$ & $\mathbf{9 5} \%$ \\
\hline vtp $_{\alpha}$ & $\mathbf{0 , 0} \%$ & $4,9 \%$ & $9,8 \%$ & $15,0 \%$ & $20,4 \%$ & $26,2 \%$ & $32,7 \%$ & $40,2 \%$ & $49,8 \%$ & $63,9 \%$ \\
\hline
\end{tabular}

Forrás: Saját számítás

\subsubsection{Ha feltesszük, hogy $X$ egyéb nevezetes eloszláscsaládba tartozik}

Mielőtt a nevezetes eloszláscsaládokra térünk, tegyünk néhány kitérőt! A szóban forgó $X$ valószínűségi változóról feltételezzük, hogy várható értéke nulla. A szóba jöhető eloszlások többségénél (pl. exponenciális, lognormális, Pareto) azonban $E(X)>0$. Ilyen esetben vagy az $X^{\prime}=X-E(X)$ transzformált valószínűségi változó kvantiliseit kell vizsgálni, vagy (ami végső soron ugyanaz) a kvantilisek várható értéktől való távolságát.
A fejezet hátralévő részében a $v t p_{\alpha}$ tőkepufferarányt keressük:

$$
v t p_{a}=\frac{V T P_{a}}{S C R}=\frac{V a R_{a}(X)-E(X)}{V a R_{99,5 \%}(X)-E(X)} .
$$

Ha $Y$ valószínűségi változó az $X$ egy konstansszorosa (azaz egy biztosító nem várt veszteségei mindig éppen megegyeznek egy másik biztosító nem várt veszteségeinek pl. hétszeresével), akkor $Y$-ra ugyanaz a $v t p_{\alpha}$ érték adódik, hiszen $\operatorname{VaR}_{\alpha}(c \cdot X)=c \cdot V a R_{\alpha}(X)$, illetve $E(c \cdot X)=c \cdot E(X)$, azaz (10)-ben lehet $c$-vel egyszerüsíteni ${ }^{17}$.

Következésképpen a $v t p_{a}$ értéke érzéketlen az eloszlás lineáris transzformációjára (eltolásinvariancia). (Például az előző fejezetben is elég lett volna csak a standard normális eloszlást vizsgálni.)

\subsubsection{Ferde normális eloszlás}

A ferdültség tőkepufferre gyakorolt hatását a ferde normális eloszláson keresztül szemléltetem. Az eloszlás sűrűségfüggvénye

$$
f(x)=2 \varphi(x) \phi(a x)^{18}
$$

ahol $\varphi$ és a $\phi$ a standard normális eloszlás eloszlásfüggvénye, illetve sűrüségfüggvénye ${ }^{19}$. Az $a$ paraméter határozza meg az eloszlás ferdeségét. $a=0$ esetén a standard normális eloszlást kapjuk, $a>0$ esetén jobbra, $a<0$ esetén balra ferde eloszlást. Minél nagyobb az $a$ paraméter abszolút értéke, annál ferdébb lesz az eloszlás ${ }^{20}$.

1.ábra: A 0 várható értéküre, 1 szórásúvá transzformált ferde normális eloszlás sürüségfüggvénye

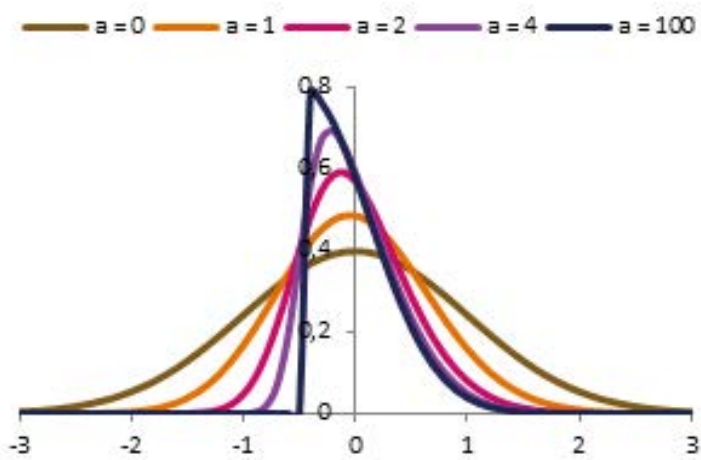

Forrás: Saját számitás 
2. ábra: A $v t p_{75 \%}$ és $v t p_{90 \%}$ értéke különbözö „a”paraméterek mellett

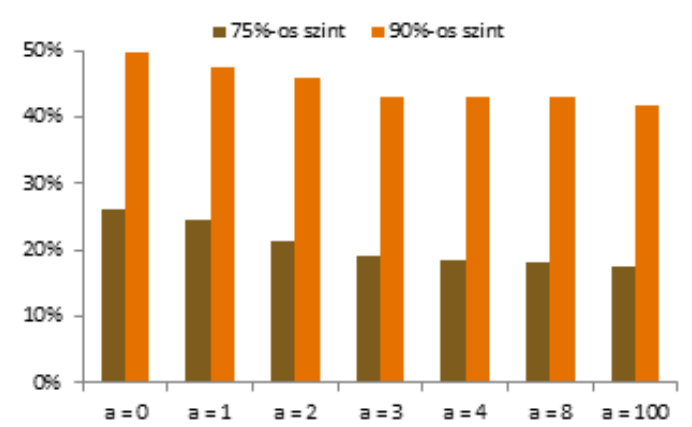

Forrás: Saját számítás

A százezer mintás szimulációs futtatások ${ }^{21}$ egyértelműen mutatják (2. ábra), hogy $v t p_{a}$ annál kisebb, minél inkább jobbra ferdül az eloszlás. Például $a=4$ mellett már egy 118,6 százalékos tőkemegfelelés is 75 százalékos védelmet biztosít, ami normális eloszlás esetén $(a=0)$ csak 126 százalékos tőkeszint mellett valósult meg.

2. táblázat: vtpa értékei ferde normális eloszlás esetén különböző $a$ paraméterek mellett

\begin{tabular}{|r|rrrrrrr|}
\hline & $\mathrm{a}=\mathbf{0}$ & $\mathrm{a}=\mathbf{1}$ & $\mathrm{a}=\mathbf{2}$ & $\mathrm{a}=\mathbf{3}$ & $\mathrm{a}=\mathbf{4}$ & $\mathrm{a}=\mathbf{8}$ & $\mathrm{a}=\mathbf{1 0 0}$ \\
\hline $\mathbf{6 5} \%$ & $15,0 \%$ & $13,6 \%$ & $10,6 \%$ & $8,6 \%$ & $7,8 \%$ & $7,2 \%$ & $6,7 \%$ \\
\hline $\mathbf{7 5} \%$ & $26,2 \%$ & $24,5 \%$ & $21,4 \%$ & $19,0 \%$ & $18,6 \%$ & $18,0 \%$ & $17,5 \%$ \\
\hline $\mathbf{8 5} \%$ & $40,4 \%$ & $38,0 \%$ & $35,7 \%$ & $33,2 \%$ & $32,9 \%$ & $32,7 \%$ & $31,8 \%$ \\
\hline $\mathbf{9 5} \%$ & $63,9 \%$ & $61,9 \%$ & $60,7 \%$ & $58,3 \%$ & $58,8 \%$ & $58,6 \%$ & $57,5 \%$ \\
\hline
\end{tabular}

Megjegyzés: százezer mintás szimuláció alapján. Forrás: Saját számitás

Arató (1995) szerint a leggyakrabban alkalmazott káreloszlások az exponenciális, a lognormális, a Pareto, illetve a gamma és a Weibull, ezért annak ellenére érdemes ezeknél az eloszláscsaládoknál is megvizsgálni a volatilitási tőkepuffer értékét, hogy a nettó eszközérték volatilitásáért általában nem elsősorban a károk volatilitása felelős.

\subsubsection{Exponenciális eloszlás}

Az exponenciális eloszlással egy olyan berendezés élettartamát lehet modellezni, ahol a tönkremenetel valószínűsége nem függ a berendezés korától („örökifúu” eloszlás).

$$
\text { Sürüségfüggvénye } \quad f(x)=\lambda e^{-\lambda x}(x>0)
$$

viszonylag gyorsan lecseng, de jelentősen jobbra ferdül. Várható értéke $E(X)=1 / \lambda$, így a nem várt veszteség $X-1 / \lambda$. Könnyen levezethetö

$$
v t p_{\alpha}=\frac{\ln (1-\alpha)-1}{\ln (1-99,5 \%)-1}
$$

azaz $v t p_{\alpha}$ nem függ a $\lambda$ paramétertől. Ezt az eltolásinvariancia alapján is tudhattuk, hiszen a $\lambda$ paraméter megváltoztatása mindössze az eloszlás lineáris transzformációját eredményezi.

\section{3. táblázat: Volatilitási tőkepuffer az SCR százalékában}

\section{\begin{tabular}{l|llllllllll|}
\hline$\alpha$ & $\mathbf{5 0} \%$ & $\mathbf{5 5} \%$ & $\mathbf{6 0} \%$ & $\mathbf{6 5} \%$ & $\mathbf{7 0} \%$ & $\mathbf{7 5} \%$ & $\mathbf{8 0} \%$ & $\mathbf{8 5} \%$ & $\mathbf{9 0} \%$ & $\mathbf{9 5} \%$ \\
\hline
\end{tabular}}

Forrás: Saját számitás

Megjegyzés: A negatív vtp $p_{\alpha}$ étékek abból adódnak, hogy (az exponenciális eloszlás erős ferdesége miatt) VaRa még viszonylag magas megbizhatósági szint mellett is kisebb, mint a várható érték.

\subsubsection{Lognormális eloszlás}

Egy valószínűségi változó eloszlása lognormális, ha logaritmusa normális eloszlású. Vagy másképpen: ha $X$ valószínűségi változó normális eloszlású, akkor $e^{X}$ lognormális eloszlású. Ennek megfelelően sürüségfüggvénye

$$
f(x)=\frac{1}{\sigma \sqrt{2 \pi x}} e^{-\frac{(\ln x-\mu)^{2}}{2 \sigma^{2}}}(x>0) .
$$

Innen adódik

$$
\operatorname{VaR}_{\alpha}=e^{\varphi^{-1(\alpha) \sigma+\mu}} \text { és, } E(X)=e^{\frac{\sigma^{2}}{2}+\mu}
$$

ami alapján

$$
v t p_{\alpha}=\frac{e^{\left(\varphi^{-1}(\alpha) \sigma+\mu\right)}-e^{\frac{\sigma^{2}}{2}+\mu}}{e^{\left(\varphi^{-1}(99,5 \%) \sigma+\mu\right)}-e^{\frac{\sigma^{2}}{2}+\mu}}=\frac{e^{\varphi^{-1}(\alpha) \sigma}-e^{\frac{\sigma^{2}}{2}}}{e^{\varphi^{-1}(99,5 \%) \sigma}-e^{\frac{\sigma^{2}}{2}}},
$$

azaz $v t p$ nem függ a $\mu$-töl ( $\Phi$ a standard normális eloszlás eloszlásfüggvénye). Ez is következik az eltolásinvarianciából, hiszen az $Y=\frac{X}{e^{\mu}}$ sürüségfüggvénye

$$
g(x)=\frac{1}{\sigma \sqrt{2 \pi x}} e^{-\frac{(\ln x)^{2}}{2 \sigma^{2}}}
$$

azaz a $\mu=0$ értéket egy lineáris transzformációval el lehet érni.

A $\sigma$ növelésével az eloszlás egyre inkább jobbra ferdül. Pearson ferdesége $\gamma=\sqrt{e^{\sigma^{2}}-1}\left(2+e^{\sigma^{2}}\right)$ rendkívül gyorsan nő a $\sigma$ függvényében. $\sigma<2 \Phi^{-1}(\alpha)$ esetében ${ }^{22}$ a tapasztalatok alapján (4. ábra) a vtp értéke a $\sigma$, tehát az eloszlás ferdeségének növelésével egyre kisebb lesz. 
3. ábra: A nulla várható értéküre eltolt lognormális 4. ábra: vtp $\propto$ értéke a $\sigma$ paraméter függvényében eloszlás sürüségfüggvénye különbözó

o-k esetén
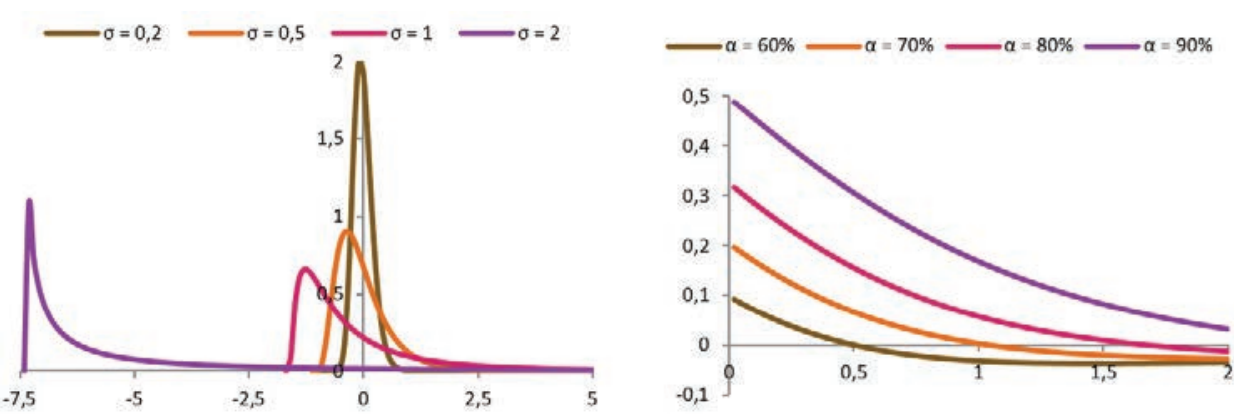

Forrás: Saját számítás

Ha a $\sigma$-val nulla felé közelítünk, akkor az eloszlás ferdesége nullához tart, és a $v t p$ értékek egyre inkább közelítik (alulról) a normális eloszlás esetében kapott értékeket, amit könnyen be lehet bizonyítani formálisan is, (18)-at fölhasználva (szintén könnyen levezethetö),

$$
\lim _{\sigma \rightarrow 0} v t p_{\alpha}=\lim _{\sigma \rightarrow 0} \frac{e^{\varphi^{-1}(\alpha) \sigma}-e^{\frac{\sigma^{2}}{2}}}{e^{\varphi^{-1}(99,5 \%) \sigma}-e^{\frac{\sigma^{2}}{2}}}=\frac{\varphi^{-1}(\alpha)}{\varphi^{1}(99,5 \%)}
$$

ami (9) alapján éppen a normális eloszlásra adódott $v t p_{\alpha}$-val egyezik meg.

4. táblázat: $v t p_{\alpha}$ értékei lognormális eloszlás esetén különbözö $\sigma$ paraméterek mellett

\begin{tabular}{|r|rrrrrr|}
\hline & $\boldsymbol{\sigma}=\mathbf{1 E}-\mathbf{1 0}$ & $\boldsymbol{\sigma}=\mathbf{0 , 1}$ & $\boldsymbol{\sigma}=\mathbf{0 , 2}$ & $\boldsymbol{\sigma}=\mathbf{0 , 5}$ & $\boldsymbol{\sigma}=\mathbf{1}$ & $\boldsymbol{\sigma}=\mathbf{2}$ \\
\hline $\mathbf{6 5} \%$ & $15,0 \%$ & $11,9 \%$ & $9,2 \%$ & $3,2 \%$ & $-1,6 \%$ & $-3,2 \%$ \\
\hline $\mathbf{7 5} \%$ & $26,2 \%$ & $22,4 \%$ & $19,0 \%$ & $10,8 \%$ & $2,7 \%$ & $-2,1 \%$ \\
\hline $\mathbf{8 5} \%$ & $40,2 \%$ & $36,1 \%$ & $32,1 \%$ & $21,9 \%$ & $10,2 \%$ & $0,3 \%$ \\
\hline $\mathbf{9 5} \%$ & $63,9 \%$ & $60,2 \%$ & $56,5 \%$ & $45,9 \%$ & $30,7 \%$ & $11,8 \%$ \\
\hline
\end{tabular}

Forrás: Saját számítás

\subsubsection{Pareto-eloszlás}

A Pareto-eloszlás az exponenciális eloszlással áll hasonló viszonyban, mint a lognormális a normálissal: ha $X(a ; c)$ paraméterű Pareto-eloszlású, akkor $\ln \left(\frac{x}{c}\right)$ a paraméterű exponenciális eloszlású (Arató 1995). Sürüségfüggvénye

$$
f(x)=\frac{a \cdot c^{a}}{x^{a+1}}
$$

ha $x>c$, egyébként 0 . A $c$ paraméter változtatása csak egy lineáris transzformációt jelent, ami nem befolyásolja a tőkepuffer értékét.

Könnyen levezethetö:

$$
v t p_{\alpha}=\frac{(1-\alpha)^{-\frac{1}{a}}-\frac{a}{a-1}}{(1-0,995)^{-\frac{1}{a}}-\frac{a}{a-1}} .
$$

5. ábra: A nulla várható értékủre eltolt Pareto-eloszlás sủrüségfüggvénye különböző $a$-k esetén $(c=1)$

6. ábra: vtp értéke az $a$ paraméter függvényében
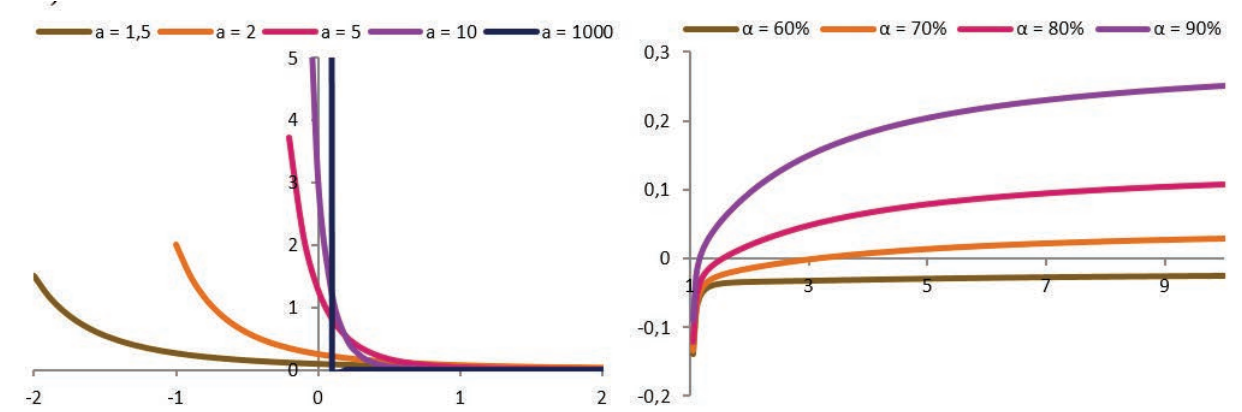

Forrás: Saját számítás

Ha $a \leq 1$, az eloszlás várható értéke végtelen, így csak 1-nél nagyobb $a$ mellett van értelme a $v t p_{\alpha}$ meghatározásának. a növelésével az eloszlás egyre vékonyabb farkú, egyre kevésbé ferdül jobbra $^{23}$ (7. ábra). A tapasztalatok szerint a számunkra érdekes esetekben (ahol $\operatorname{VaR}_{\alpha}(X)>E(X)$ ), az a növelésével egyre nagyobb tőkepuffer adódik bármely rögzített megbízhatósági szint esetén, tehát itt is igaz, hogy a ferdeség növelésével, illetve az eloszlás farokrészének vastagításával csökken $a$ értéke. Inkább elméleti szempontból érdekes a $v t p_{\alpha}$ határértékét vizsgálni, ha az $a$ a végtelenbe tart. Könnyen levezethető

$$
\lim _{a \rightarrow \infty} v t p_{\alpha}=\frac{\ln (1-\alpha)+1}{\ln (1-99,5 \%)+1},
$$

ami csak akkor pozitív, ha a>1-(1/e) 63,2\%, azaz 63,2\%-nál kisebb megbízhatósági szint esetén minden Pareto-eloszlású veszteségfüggvénynél negatív volatilitási tőkepuffer adódik. Általában $\operatorname{VaR}_{\alpha}(X)>E(X)$ akkor teljesül, ha $\alpha>1-(1-1 / \alpha)^{\alpha}$. Az egyes $a$-khoz tartozó küszöb $\alpha$-kra az 5. táblázat ad eligazítást. 
5. táblázat: vtp ${ }_{a}$ értékei Pareto-eloszlás esetén különböző $a$ paraméterek mellett

\begin{tabular}{|rrrrrrr|}
\hline & $\mathrm{a}=\mathbf{1 , 5}$ & $\mathrm{a}=\mathbf{2}$ & $\mathrm{a}=\mathbf{5}$ & $\mathrm{a}=\mathbf{1 0}$ & $\mathrm{a}=\mathbf{1 0 0 0}$ & $\mathrm{a}=1 \mathrm{E}+09$ \\
\hline $\mathbf{6 0} \%$ & $-3,7 \%$ & $-3,4 \%$ & $-3,0 \%$ & $-2,6 \%$ & $-2,0 \%$ & $-1,9 \%$ \\
\hline $\mathbf{6 5} \%$ & $-3,2 \%$ & $-2,6 \%$ & $-1,0 \%$ & $-0,1 \%$ & $1,1 \%$ & $1,2 \%$ \\
\hline $75 \%$ & $-1,5 \%$ & $0,0 \%$ & $4,3 \%$ & $6,4 \%$ & $9,0 \%$ & $9,0 \%$ \\
\hline $\mathbf{8 5} \%$ & $1,7 \%$ & $4,8 \%$ & $12,9 \%$ & $16,6 \%$ & $20,8 \%$ & $20,9 \%$ \\
\hline $95 \%$ & $14,0 \%$ & $20,4 \%$ & $34,9 \%$ & $40,5 \%$ & $46,4 \%$ & $46,4 \%$ \\
\hline
\end{tabular}

Forrás: Saját számitás

Az egyes eloszláscsaládok esetében a paraméterek változtatásával nemcsak a $V a R_{\alpha}$ és $V a R_{99,5 \%}$ várható értéktől vett távolsága változik, hanem az ezek közötti viszony is. Ha $\alpha<99,5 \%$, akkor $V a R_{\alpha}<V a R_{99.5 \%}$, de a várható érték bárhol elhelyezkedhet ezekhez viszonyítva. Például, ha az a paraméterrel jobbról közelítünk az 1-hez, akkor mindhárom érték növekszik, de a várható érték növekszik a leggyorsabban, elöször a $V a R_{\alpha}$ majd a $V a R_{99,5 \%}$ értékét „elözi be”. Így a $v t p_{\alpha}=\frac{(1-\alpha)^{-1 / a}-\frac{a}{a-1}}{(1-0,995)^{-1 / a}-\frac{a}{a-1}}$ mint az a paraméter függvénye, bármely $\alpha<99,5 \%$ esetén

negatívvá válik, és elöször a mínusz végtelenhez tart, majd egy szakadást követően a plusz végtelen felől az 1-hez ${ }^{24}$ (8. ábra). Azaz Pareto-eloszlást feltételezve is a volatilitási tőkepufferre bármilyen érték is adódhat (ld. még a 4.2.1. fejezetet).

7. ábra: A Pareto-eloszlás Pearson-ferdesége az $a$

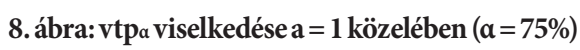
paraméter függvényében $(c=1)$.
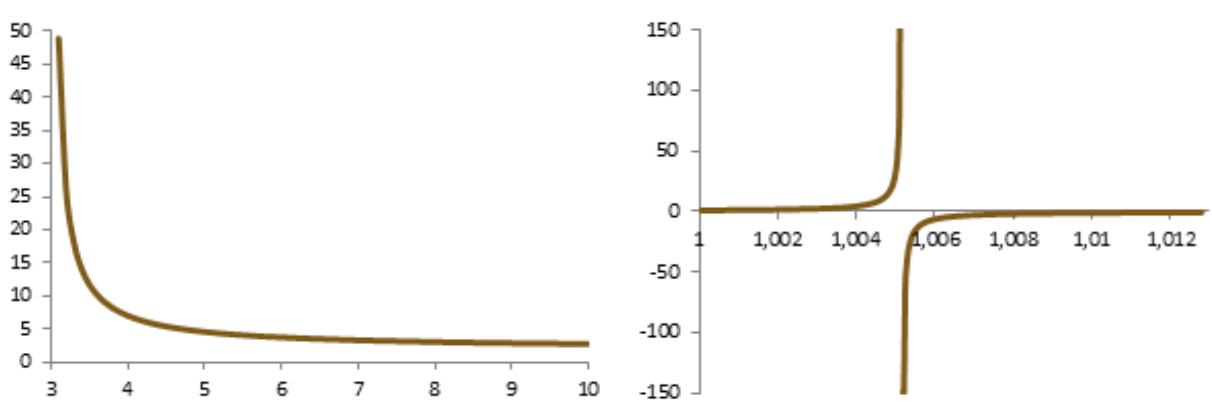

Forrás: Saját számítás

\subsubsection{Gamma-eloszlás}

A gamma-eloszlás sürüségfüggvénye:

$$
f(x)=\frac{\lambda^{p} x^{p-1} e^{-\lambda x}}{\Gamma(p)}
$$

ami $p=1$ esetén épp az exponenciális eloszlás sűrüségfüggvényével egyezik meg. $(\Gamma(\mathrm{p})$ a gammafüggvény ${ }^{25}$.) $p \leq 1$ esetén $f(x)$ a végtelenhez tart, ha $x$ (pozitív oldalról) tart a nullához, $p>1$ esetén pedig a nullához. A $p$ növelése vékonyítja az eloszlás farkát ${ }^{26}$, és csökkenti a ferdeséget, míg a $\lambda$ változtatása csak egy lineáris transzformációt jelent, tehát számunkra indifferens.

Gamma-eloszláshoz jutunk $p \mathrm{db}$ teljesen független $\lambda$ paraméterű exponenciális eloszlás konvolúciója $\mathrm{a}^{27}$ által is (Bowers et al. 1997). A centrális határeloszlás tétel következtében a gamma-eloszlás standardizáltjának ${ }^{28}$ eloszlása a $p$ növelésével egyre inkább közelít a standard normális eloszláshoz. Így - miután a $v t p_{\alpha}$ invariáns az eloszlás lineáris transzformációjára - nem meglepő, hogy nagy $p$ esetén adódó $v t p_{\alpha}$ értékek nagyon hasonlítanak a normális eloszlás esetén kapott számokhoz.

9. ábra: A nulla várható értéküre eltolt gamma-eloszlás $\quad 10$. ábra: vtp a értéke a $p$ paraméter függvényében sürüségfüggvényei különbözö $p$-k esetén $(\lambda=1)$
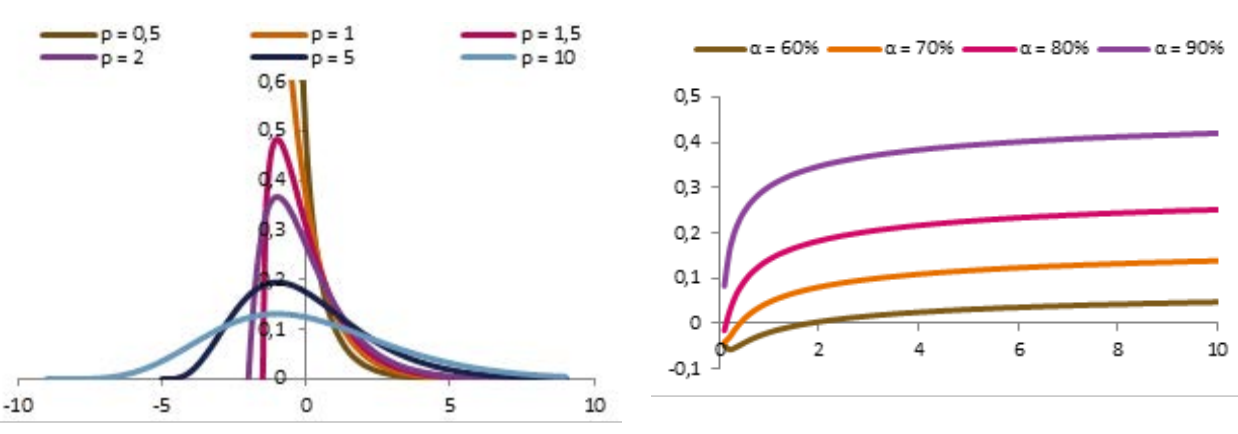

Forrás: Saját számítás

A tapasztalatok alapján $v t p$ értéke a pozitív tartományon rögzített $\alpha$ esetében növekszik, ha $p$ nő, azaz itt is teljesül, hogy a ferdeség növelésével, illetve az eloszlás farokrészének vastagításával csökken a tőkepuffer értéke.

6. táblázat: vtp $p_{\mathfrak{a}}$ értékei gamma-eloszlás esetén különbözö $p$ paraméterek mellett

\begin{tabular}{|r|rrrrrrr|}
\hline & $\mathbf{0 , 5}$ & $\mathbf{1}$ & $\mathbf{1 , 5}$ & $\mathbf{4}$ & $\mathbf{1 0}$ & $\mathbf{1 0 0 0}$ & $\mathbf{1 E + 0 9}$ \\
\hline $\mathbf{6 5} \%$ & $-1,8 \%$ & $1,2 \%$ & $2,9 \%$ & $6,5 \%$ & $9,1 \%$ & $14,3 \%$ & $15,0 \%$ \\
\hline $\mathbf{7 5} \%$ & $4,7 \%$ & $9,0 \%$ & $11,3 \%$ & $15,9 \%$ & $19,1 \%$ & $25,4 \%$ & $26,2 \%$ \\
\hline $\mathbf{8 5} \%$ & $15,6 \%$ & $20,9 \%$ & $23,6 \%$ & $28,9 \%$ & $32,5 \%$ & $39,4 \%$ & $40,2 \%$ \\
\hline $\mathbf{9 5} \%$ & $41,3 \%$ & $46,4 \%$ & $48,9 \%$ & $53,8 \%$ & $57,1 \%$ & $63,1 \%$ & $63,9 \%$ \\
\hline
\end{tabular}

Forrás: Saját számitás 


\subsubsection{Weibull-eloszlás}

A Weibull-eloszlás szintén az exponenciális eloszlás kiterjesztése. Sürűségfüggvénye

$$
f(x)=\frac{k}{\lambda} \cdot\left(\frac{x}{\lambda}\right)^{k-1} \cdot e^{-\left(\frac{x}{\lambda}\right)^{k}}(x \geq 0, k, \lambda>0)
$$

A tönkremenésig (halálozásig) eltelt időt lehet ezzel modellezni. $k<1$ esetén az idő előrehaladtával csökkenő (pl. csecsemőhalandóság), $k>1$ esetén növekvő (pl. gépkopás, időskori halandóság) valószínűségű véget, $k=1$ esetén időtől független tönkremenetelt (pl. villanykörte) modellez. A $k$ növelése csökkenti az eloszlás ferdeségét, és vékonyítja az eloszlás farkát (ld. 23. lábjegyzet).

A tőkepuffer mértéke itt is könnyen levezethető:

$$
v t p_{\alpha}=\frac{(-\ln (1-\alpha))^{\frac{1}{k}}-\Gamma\left(1+\frac{1}{k}\right)}{(-\ln (1-99,5 \%))^{\frac{1}{k}}-\Gamma\left(1+\frac{1}{k}\right)},
$$

ahol $\Gamma$ a már korábban említett gammafüggvény. A kapott kifejezés az eltolásinvariancia miatt nem függ $\lambda$-tól.

11. ábra: A nulla várható értéküre eltolt Weibulleloszlás sürüségfüggvényei különböző $k$ paraméterek esetén $(\lambda=1)$
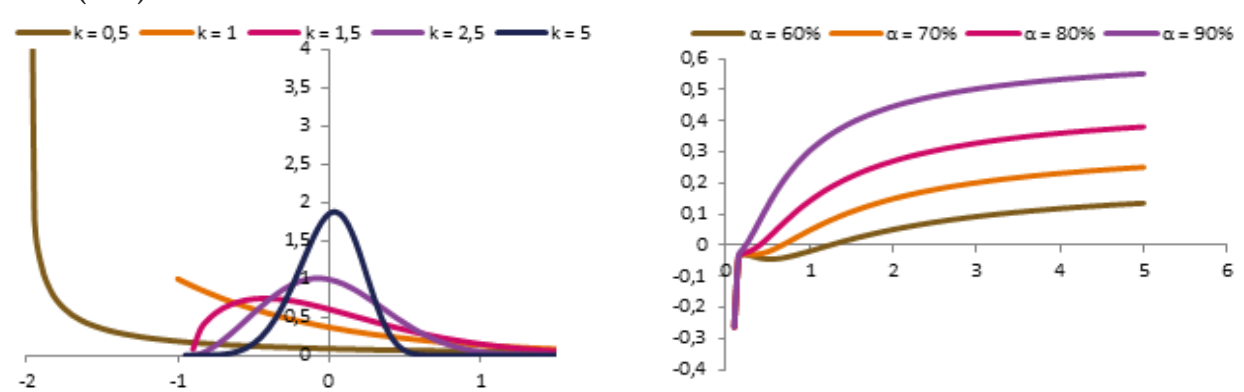

Forrás: Saját számitás

A tapasztalatok alapján $v t p_{\alpha}$ a pozitív tartományon monoton növekszik, ha a $k$ értékét növeljük ${ }^{29}$, azaz itt is fönnáll, hogy a nagyobb ferdeséghez, illetve vastagabb farkú eloszláshoz kisebb tökepuffer tartozik. $k$-val 0 felé tartva egyre nagyobb megbízhatósági szinteken is negatív tőkepuffer adódik. Belátható, hogy ha a $k$ értékét minden határon túl növeljük, akkor a $v t p_{\alpha}$ határértéke

$$
\lim _{k \rightarrow \infty} v t p_{\alpha}=\frac{\ln (-\ln (1-\alpha))-\gamma}{\ln (-\ln (1-99,5 \%))-\gamma},
$$

ahol $\gamma$ az Euler-Mascheroni gamma ( 0,5772) (Jeffrey C. Lagarias 2013)

7. táblázat: vtpa értékei Weibull-eloszlás esetén különbözö $k$ paraméterek mellett

\begin{tabular}{|r|rrrrrr|}
\hline & $\mathbf{0 , 5}$ & $\mathbf{1}$ & $\mathbf{1 , 5}$ & $\mathbf{2 , 5}$ & $\mathbf{5}$ & $\mathbf{1 0 0 0}$ \\
\hline $\mathbf{6 5} \%$ & $-3,4 \%$ & $1,2 \%$ & $6,1 \%$ & $12,5 \%$ & $19,2 \%$ & $27,8 \%$ \\
\hline $\mathbf{7 5} \%$ & $-0,3 \%$ & $9,0 \%$ & $15,9 \%$ & $23,8 \%$ & $31,3 \%$ & $40,2 \%$ \\
\hline $\mathbf{8 5} \%$ & $\mathbf{6 , 1 \%}$ & $20,9 \%$ & $29,5 \%$ & $38,1 \%$ & $45,7 \%$ & $54,2 \%$ \\
\hline $\mathbf{9 5 \%} \%$ & $26,8 \%$ & $46,4 \%$ & $55,0 \%$ & $62,6 \%$ & $68,5 \%$ & $74,6 \%$ \\
\hline
\end{tabular}

4.2. Az eloszlás általános jellemzői alapján végzett becslések

\subsubsection{Tetszőleges eloszlás}

Egy biztosító veszteségének valódi eloszlása egyik eloszláscsaládba sem tartozik, azaz bármely eloszláscsaládot is feltételezzük, nem garantálható, hogy az annak alapján meghatározott tőkepuffer a megcélzott megbízhatósági szinten garantálja az előírt tőkemegfelelést a köztes időszakban. Lehet-e találni olyan univerzális $p_{-} f e l s o_{\alpha}$, illetve $p_{-} a l s o_{\alpha}$ paramétert, hogy tetszőleges nulla várható értékű $X$ eloszlásfüggvény esetén

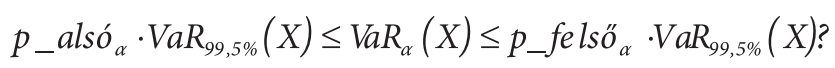

A 4.2.2.4. fejezetben láthattuk, hogy ilyen univerzális paraméterek még akkor sem léteznek, ha az X-ről azt feltételezzük, hogy Pareto-eloszlású. Itt azonban az igazán érdekes esetre, amikor a várható érték mind a $\operatorname{VaR}_{\alpha}(X)$-nél, mind a $\operatorname{VaR}_{99,5 \%}(X)$-nél nagyobb, kaptunk egy $\frac{\ln (1-\alpha)+1}{\ln (1-99.5 \%)+1}$ abszolút felső korlátot.

Az alábbi egyszerü példák mutatják, hogy ha az $X$-röl nem tételezünk föl semmit (az $E(X)=0$-n kívül), akkor a

$$
\frac{\operatorname{VaR}_{\alpha}(X)}{\operatorname{VaR}_{99,5 \%}(X)}=\frac{\operatorname{VaR}_{\alpha}(X)}{S R C}
$$

hányados akármekkora is lehet.

Tekintsük az alábbi eloszláscsaládot, amelynek sűrüségfüggvénye ${ }^{30}$.

$$
f(x)=\left\{\begin{array}{l}
\text { A, ha } 0 \leq x<1 \\
B, \text { ha } 1 \leq x \leq b+1 \\
\text { o egyébként }
\end{array}\right.
$$




\section{3. ábra: A példában szereplő eloszlás sủrüségfüggvénye}

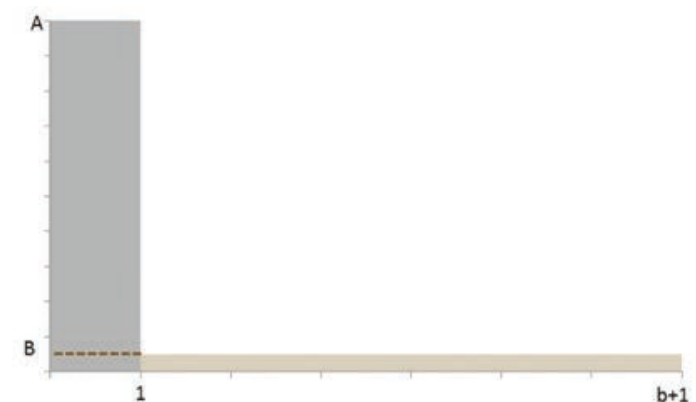

Forrás: Saját számitás

$A=0,995, B=0,0000125, b=400$ mellett az $X$ várható értéke $E(X)=1,5$, míg a 99,5 százalékos kvantilise $\operatorname{VaR}_{99,5 \%}(X)=1$ lesz. Ha egy biztosító vesztesége ilyen eloszlású lenne, ez azt jelentené, hogy a nem várt veszteségének a 99,5 százalékos kvantilise, azaz szavatolótőke-szükséglete $S C R=V a R_{99,5 \%}(X)-E(X)=-0,5$, azaz negatív lenne. Ha rögzített $B=0,0000125$ mellett az $A$-t fokozatosan csökkentjük a kritikus 0,99499368712625 értékre (és ezzel együtt a $b$-t úgy növeljük, hogy az $f(x)$ sűrűségfüggvény maradjon $\left.{ }^{31}\right)$, a $\operatorname{VaR}_{99,5 \%}(X)-E(X)$ negatív oldalról fokozatosan tart nullához, miközben tetszőleges $\alpha<99 \%$-os megbízhatóság mellett a $\operatorname{VaR}_{\alpha}(X)$ mindig -1,5 és -0,5 közé esik, azaz

$$
\lim \frac{\operatorname{Var}_{\alpha}(X)-E(X)}{S C R-E(X)}=+\infty
$$

Hasonló megfontolások alapján a hányados a mínusz végtelenhez tart, ha az $A$-t fokozatosan növeljük a kritikus 0,99499368712625 érték felé. Tehát a $v t p_{\alpha}$ bármilyen értéket fölvehet.

A keresett hányadosra még abban az esetben is csak a triviális

$$
0 \leq \frac{\operatorname{VaR}_{\alpha}(X)}{\operatorname{VaR}_{99,5 \%}(X)}=\frac{\operatorname{VaR}_{\alpha}(X)}{S C R} \leq 1
$$

becslést tudjuk adni, ha feltételezzük, hogy mind az $S C R$, mind pedig a VaR pozitív. A fenti eloszlást alapul véve tetszőleges $\alpha$-hoz található olyan $A$ (és a megfelelő $b$ ), hogy $\operatorname{VaR}_{\alpha}(X)-E(X)=0$ legyen, azaz a fenti triviális becslés bal oldalánál jobbat általában nem lehet adni. Ugyanezen példánál maradva az $A$-t rögzítsük az $A=\alpha$ értékre! Ha a $B$-vel tartunk a plusz végtelenhez (és ezzel együtt a $b$-t megfelelően módosítjuk, hogy $A+b^{*} B=1$ maradjon), akkor a $\quad \frac{\operatorname{VaR}_{\alpha}(X)}{S C}$ hányados 1-hez tart, azaz általában a triviális egyenlőtlenség jobb oldalánál sem lehet jobbat mondani, a nem várt veszteség eloszlására egyéb feltételezésekkel is kell élni.

\subsubsection{Csökkenő valószínűségü nem várt veszteségek}

Természetes feltételezés, hogy a nem várt veszteség valószínűsége annál kisebb, minél nagyobb a veszteség mértéke, pontosabb megfogalmazásban: $P(a<X<a+\varepsilon) \leq P(b<X<b+\varepsilon)$, ha $a \geq b>0$, ahol $X$ a nem várt veszteség, $\varepsilon$ tetszőleges pozitív szám. Ha $X$ eloszlásának van $f$ eloszlásfüggvénye, akkor ez a feltétel ekvivalens azzal, hogy az $f$ monoton csökkenő a $[0 ; \infty)$ intervallumon. Nem nehéz belátni, hogy ekkor $\alpha<99,5 \%$ esetén

$$
\frac{\operatorname{VaR}_{\alpha}(X)}{\operatorname{VaR}_{99,5 \%}(X)}=\frac{\operatorname{VaR}_{\alpha}(X)}{S C R} \leq \frac{\alpha-p}{99,5 \%-p}
$$

ahol $p=P(X<0)=\int_{-\infty}^{0} f$

Ha az $X$ szimmetrikus eloszlású (azaz $f$ páros függvény), akkor $p=0,5$. A normális eloszlás feltételezésével szembeni legfóbb érv, hogy általában a nem várt veszteségek mértéke meghaladja a nem várt nyereség mértékét, a nem várt veszteségek átlaga tipikusan nagyobb a nem várt nyereségek átlagánál.

Jelöljük $V$-vel a nem várt veszteségek átlagát!

$$
V=E(X \mid X>0)
$$

ahol $E(X \mid X>0)$ az $X$ feltételes várható értékét jelenti az $X>0$ feltétel mellett. A nem várt nyereségekét jelöljük $N$-nel!

$$
N=-E(X \mid X<0)
$$

Tekintettel arra, hogy $E(X)=0$, azaz $E\left(X^{+}\right)=-E\left(X^{-}\right)$, ahol $X^{+}=\max (X ; 0), X^{=}=\min (X ; 0)$, továbbá arra, hogy $E(X \mid X>0)=E\left(X^{+}\right) / P(X>0)$ és $E(X \mid X<0)=E(X) / P(X<0)$ következik

$$
\frac{p}{1-p}=\frac{V}{N}
$$

ahol $p=P(X<0)$ a fentieknek megfelelően. Ha az átlagos nem várt veszteség nagyobb az átlagos nem várt nyereségnél, azaz $V>N$, akkor $p>0,5$. Miután a $\frac{\alpha-p}{99,5 \% p}$ kifejezés monoton csökken $p$-ben, a $V>N$ az esetben (35) teljesül minden $\alpha<99,5 \%$ megbízhatósági szintre:

$$
\frac{\operatorname{VaR}_{\alpha}(X)}{\operatorname{VaR}_{99,5 \%}(X)}=\frac{\operatorname{VaR}_{\alpha}(X)}{S C R} \leq \frac{\alpha-0,5}{99,5 \%-0,5}
$$

Következésképpen például $v t p_{750} \leq 0,505$, azaz 150,5 százalékos tőkeszint esetén minden olyan biztosító legalább 75 százalékos valószínűséggel meg fog felelni a tőkekövetelményeknek, amelyik nem várt veszteségének eloszlása kielégíti az alábbi két feltételt: (i) a nagyobb nem várt veszteségek kisebb valószínűséggel fordulnak elő; (ii) a nem várt veszteségek átlagosan nagyobbak a nem várt nyereségeknél. 
De ha például tudjuk, hogy a nem várt veszteségek átlaga legalább kétszer akkora, mint a nem várt nyereségeké (ekkor $p \geq 2 / 3$ ), akkor már 125,4 százalékos tőkeszint is legalább 75 százalékos valószínűséggel elegendő az egyéves időtávon történő tőkemegfeleléshez.

8. táblázat: Felső becslés a vtpa értékére a nem várt veszteségek és nem várt nyereségek átlaga hányadosának $(\mathrm{V} / \mathrm{N})$ függvényében.

\begin{tabular}{|r|rrrrrr|}
\hline V/N & 1 & 1,2 & 1,5 & 2 & 4 & 10 \\
\hline $\mathbf{6 5} \%$ & $30,3 \%$ & $23,3 \%$ & $12,7 \%$ & $-5,1 \%$ & $-76,9 \%$ & $-301,6 \%$ \\
\hline $\mathbf{7 5} \%$ & $50,5 \%$ & $45,5 \%$ & $38,0 \%$ & $25,4 \%$ & $-25,6 \%$ & $-185,2 \%$ \\
\hline $\mathbf{8 5} \%$ & $70,7 \%$ & $67,7 \%$ & $63,3 \%$ & $55,8 \%$ & $25,6 \%$ & $-68,8 \%$ \\
\hline $\mathbf{9 5} \%$ & $90,9 \%$ & $90,0 \%$ & $88,6 \%$ & $86,3 \%$ & $76,9 \%$ & $47,6 \%$ \\
\hline
\end{tabular}

Forrás: Saját számitás

\subsubsection{Egyre kisebb mértékben csökkenő valószínüségű nem várt veszteségek}

Az előző fejezetben azzal a természetes feltételezéssel éltünk, hogy az egyre nagyobb veszteségek valószínűsége egyre kisebb, azaz hogy a nem várt veszteség eloszlásának $f(x)$ sürüségfüggvénye monoton nem növekvő, ha $x>0(E(X)=0)$. Különösen vastagabb farkú, illetve erősen jobbra ferdülő eloszlások esetén feltételezhető, hogy ugyan az egyre nagyobb veszteségek valószínűsége egyre kisebb, de a csökkenés intenzitása is egyre kisebb, azaz a sürüségfüggvény monoton csökkenő és konvex $x>0$ esetén $(E(X)=0)$.

14. ábra: A példában szereplő eloszlás sürüségfüggvénye

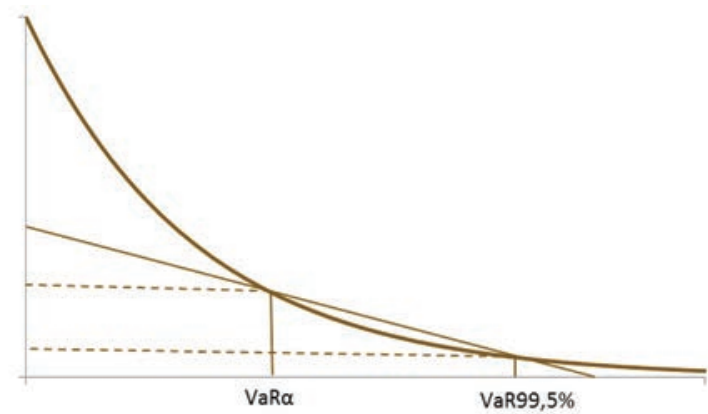

Forrás: Saját számitás

Felhasználva, hogy a sűrűségfüggvény görbéjéhez az $\alpha$, illetve 99,5 százalékos kvantilisekhez behúzott szelő a sürüségfüggvény alatt halad, ha $0<x<V a R$ és ha $V a R_{995^{\circ}}<x$, illetve fölötte, ha $\operatorname{VaR}_{\alpha}<x<\operatorname{VaR}_{99,5 \%}$ (14. ábra), adódik az alábbi egyenlőtlenség:

$$
v t p_{\alpha}=\frac{V a R_{\alpha}}{V a R_{99,5 \%}} \geq \frac{\sqrt{1-p}-\sqrt{1-\alpha}}{\sqrt{1-p}-\sqrt{1-99,5 \%}} \text {, ahol }
$$

a korábbiaknak megfelelöen $\quad p=P(X<0)=\int_{-\infty}^{0} f$.

Szimmetrikus esetben, illetve ha a nem várt veszteségek átlaga megegyezik a nem várt nyereségek átlagával (azaz $p=0,5$ ), akkor legalább 132,5 százalékos tőkeszint kell a 75 százalékos megbízhatósági szinthez. A fejezet elején tett feltételezésekhez azonban inkább egynél nagyobb $V / N$ arány illeszkedik. Például az előző fejezetben is említett $V / N=2$ esetén legalább 115,3 százalékos tőkeszint kell a 75 százalékos megbízhatósághoz. Az előző fejezet eredményeit is felhasználva a megcélzandó tőkeszint valahol 115,3 és 125,4 százalék közé esik ebben az esetben.

9. táblázat: Alsó becslés a vtpa értékére a nem várt veszteségek és nem várt nyereségek átlaga hányadosának $(\mathrm{V} / \mathrm{N})$ függvényében

\begin{tabular}{|r|rrrrrrr|}
\hline V/N & 1 & 1,2 & 1,5 & 2 & 4 & 10 \\
\hline $\mathbf{6 5} \%$ & $18,1 \%$ & $13,7 \%$ & $7,3 \%$ & $-2,8 \%$ & $-38,4 \%$ & $-125,7 \%$ \\
\hline $\mathbf{7 5} \%$ & $32,5 \%$ & $28,9 \%$ & $23,6 \%$ & $15,3 \%$ & $-14,0 \%$ & $-86,0 \%$ \\
\hline $\mathbf{8 5} \%$ & $50,3 \%$ & $47,5 \%$ & $43,6 \%$ & $37,5 \%$ & $15,9 \%$ & $-37,2 \%$ \\
\hline $\mathbf{9 5} \%$ & $76,0 \%$ & $74,7 \%$ & $72,8 \%$ & $69,8 \%$ & $59,4 \%$ & $33,8 \%$ \\
\hline
\end{tabular}

Forrás: Saját számitás

\subsection{Empirikus szórás alapján végzett becslés}

Az 1. fejezetben megfogalmazott megfontolások alapján a volatilitási tőkepuffernek adott $\alpha$ megbízhatósági szint mellett egyéves időtávon kellene szavatolnia, hogy a biztosító szavatoló tőkéje a régi, illetve a következő 12 hónap alatt várhatóan szerzett állományán a környezeti változások miatt elszenvedett nem várt veszteségek miatt ne csökkenjen a legutoljára meghatározott szavatolótőke-szükséglet szintje alá. Az empirikus megközelítés 3.3. fejezetben felsorolt nehézségei mellett az egyik legfőbb probléma, hogy kifejezetten a fenti körülmények miatti tőkecsökkenésre vonatkozó adatunk nincsen, és a későbbiekben is csak becsléseket lehet rá végezni.

A rendelkezésre álló adatok közül a fentiek alapján vizsgálandó mennyiséghez legközelebb a nettó eszközérték változása áll, amit korrigálni kell a külső tőkemozgásokkal (tőkefeltöltés, osztalék). Ehhez a QIS5 (2010), QIS5bis (2011), a 2012-es, 2014-es hatástanulmányok, illetve a RIGL előzetes S2-es adatszolgáltatás adatait (2015) használhatjuk fel. Az összevetésbe csak azokat a biztosítókat érdemes bevonni, amelyek a fenti öt adatszolgáltatásból legalább négy- 
ben részt vettek, bár még négy- vagy ötelemü minta esetében sem lehet megbízhatóan szórást becsülni. Az eredményt tovább kellene korrigálni az új állomány várható eredményével, erre azonban nincs mód. A volatilitást egyes esetekben jelentősen befolyásolhatta, hogy a biztosítók az adatszolgáltatásokat „best effort” alapján teljesítették, és így az adatok nem fedték le teljes mértékben a Szolvencia II rezsim által megfogalmazott célokat.

A 3.3. fejezetnek megfelelően a 75 százalékos megbízhatósági szinthez a 2/3-os szabályt alkalmazhatjuk, amelynek alapján az empirikus volatilitási tőkepuffer az előző bekezdésnek megfelelöen korrigált nettó eszközértékek szórásának 2/3-a. Ha az empirikus tőkepuffer értékét visszaforgatjuk megcélzandó tőkeszintté, azaz elosztjuk az SCR értékével, akkor - normális eloszlást feltételezve - 26,2 százalék körüli addicionális tőkeszinteket kellene kapnunk.

\section{5. ábra: Empirikus volatilitási tőkepuffer az SCR arányában}
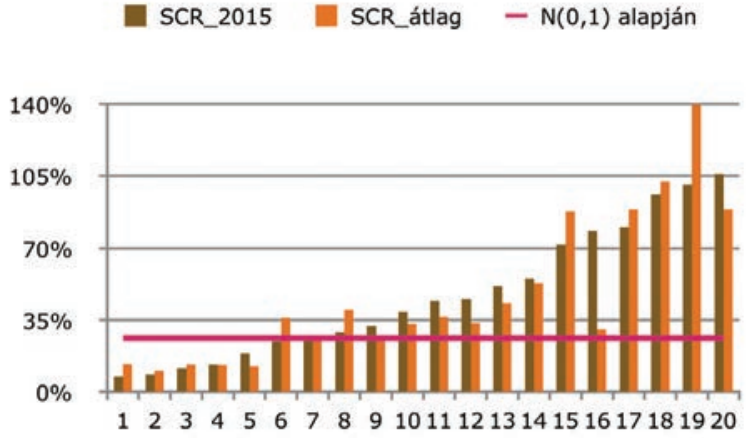

Forrás: QIS5 (2010), QIS5bis (2011), a 2012-es, 2014-es hatástanulmányok, illetve a RIGL elözetes S2-es adatszolgáltatás

A fentiek alapján azonban a kijött eredményeket nagy fenntartással kell kezelni. Nem meglepő, hogy az empirikus adatok alapján a szóba jöhető 20 biztosító 65 százalékánál nagyobb tőkepuffer adódik, mint a normális eloszlást feltételező (egyébként inkább felső becslést eredményező) elméleti modellből, és 35 százalék esetén már több mint kétszeres az eltérés.

Tekintettel arra, hogy az empirikus adatok különböző időszakokhoz, különböző állapotokhoz tartoznak, az összevetést (visszaforgatást) érdemes a korábbi SCR-ek átlagával is elvégezni, az empirikus és elméleti megközelítés közötti különbség azonban így is alig csökken.

\section{5. Összegzés}

A volatilitási tőkepuffer - mint a tőkekövetelményeken felül tartott tőke - annak kockázatát hivatott csökkenteni, hogy a biztosító szavatoló tőkéje a legutóbb meghatározott és jelentett tőkeszükséglet alá csökken azon köztes időszakban, amikor szavatoló tőkéjét nem határozza meg. A cikkben ennek egy olyan megközelítését részletezem, amivel a feladat visszavezet- hető ugyanazon valószínűségi változó adott megbízhatósági szinthez tartozó kvantilisének keresésével, amelynek 99,5 százalékos kvantilise a szavatolótőke-szükséglet (SCR).

Az SCR standard formuláját alapul véve ezzel a megközelítéssel a VTP a biztosító alapvető szavatoló tőkéjének (nettó eszközértékének) a meglévő és a következő 12 hónapban várhatóan szerzett állományán elszenvedett nem várt veszteség miatti tőkeelégtelenség kockázatát csökkenti. Az így adódó többlettőkeigényt jelentősen felülírhatja például a biztosító régi szerződésállományának várható megújításából fakadó várható nyereség.

A megközelítésből fakadóan a VTP értéke az SCR-rel arányos. Az így adódó $v t p=V T P / S C R$ arányra bármilyen érték is adódhat, ha a nem várt veszteség eloszlására nem teszünk megszorításokat. Normális eloszlást feltéve a 75 százalékos megbízhatósági szinthez 26,2, a 90 százalékoshoz 49,8 százalékos VTP-arány tartozik. A káreloszlások modellezéséhez használt eloszláscsaládok esetében a VTP értéke (esetenként - pl. Pareto - szélsőséges mértékben) függhet az eloszlás paramétereitől: minél vastagabb farkú, illetve minél jobbra ferdül az eloszlás, annál kisebb arányú tőkepuffer adódik.

Bizonyos észszerü általános feltételezések mellett is szűk korlátok közé szorítható a tőkepuffer értéke. Ha feltesszük, hogy az eloszlás sűrűségfüggvénye monoton csökkenő és konvex a $(0 ; \infty)$ intervallumon, akkor a veszteség várható értéke $(V)$ és a nyereség várható értéke $(E)$ arányának függvényében a VTP-re egymáshoz közeli alsó és felső becsléseket adhatunk. Például 75 százalékos megbízhatósági szint esetében $V / E=1$ arány mellett a $V T P 32,5$ és 50,5 százalék közé, $V / E=2$ mellett 15,3 és 25,4 százalék közé esik.

A fenti vizsgálatok és számítások azt mutatják, hogy a biztosítók által megcélzandó, illetve a felügyelet által elvárható tőkepuffert alapvetően befolyásolja - többek között - a feltételezett eloszlás, a kitűzött megbízhatósági szint, a jövőbeni állomány várható nyereségének/ veszteségének figyelembevétele, de a végső mérték meghatározása során egyéb szempontok is felmerülhetnek (pl. prudens elvárás, egyszerüség). 


\section{IRODALOMJEGYZÉK}

Arató Miklós (1995): Altalános biztositásmatematika, jegyzet, pp. 33-52. Azzalinil: A very brief introduction to the skew-normal distribution. http://azzalini.stat.unipd.it/SN/Intro/intro.html. Letöltés ideje: 2015. szeptember 11.

Azzalini2:Random numbers with SN or ST distribution. http://azzalini.stat.unipd.it/SN/faq-r.html. Letöltés ideje: 2015. szeptember 11.

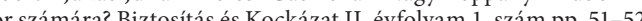
Bowers, N. L. - Gerber, H. U. - Hickman, J. C. - Jones, D. A. - Nesbitt, C. J. (1997): Actuarial Mathematics, The Society of Actuaries, 1997, p. 377.

OPA (2011): EIOPA Report on the fifth Quantitative Impact Study (QIS5) for Solvency II, pp. 26. https://eiopa.europa.eu/ Publications/Reports/QIS5_Report_Final.pdf. Letöltés ideje: 2016. január 19.

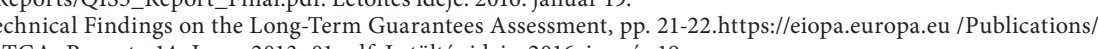
QPA (2014): EIOPA Insurance stress test 2014, pp. 51-52. https://eiopa.europa eu/Publications/Surveys/Stress\%20Test $\% 20$ Report\%202014.pdf. Letöltés ideje: 2016. január 19.

Insurance Europe (2013): The package of measures to avoid artificial volatility and pro-cyclicality. http://www.insuranceeurope. $\mathrm{eu} /$ sites/default/files/attachments/The\%20package\%20 of\%20measuresEIOPA

Weries) of theAmericanMathematical Society Volume 50, Number 4, October 2013, pp. 527-628Article electronically published on July 19, 2013 , http://www.ams.org/journals/bull/2013-50-04/S0273-0979-2013-01423-X/S0273-0979-2013-01423-X.pdf. Letöltés ideje: 2015. szeptember 11

htp://dx.doi.org/10.1090/s0273-0979-2013-01423-x eje: 2016. január 19.

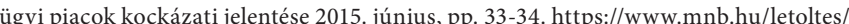
bankszektoron-kivuli-penzugyi-piacok-kockazati-jelentese-2015-junius-1.pdf. Letöttés ideje: 2016. január 19.

\section{HIVATKOZÁSOK}

${ }^{1}$ A volatilitási tőkepuffer fogalma 2014-ben jelent meg elöszzör a Magyar Nemzeti Bank kommunikációjában.

${ }^{2}$ The notion of volatility capital buffer appeared in the communication of the Magyar Nemzeti Bank for the first time in 2014 ${ }^{3}$ Long Term Guarantee Assesment

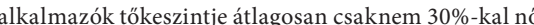

(PSZÁF - 2012): QIS 2014 (MNB - 2014): RIGL (felkészülési célú adatszolgáltatás - 2015) - minden esetben a hatástanulmány végrehajtásának évét megelőző év végi adatokon.

${ }^{6}$ Tökearányos lefedettségük $64-75 \%$.

${ }^{7}$ A szórás és a várható érték hányadosa.

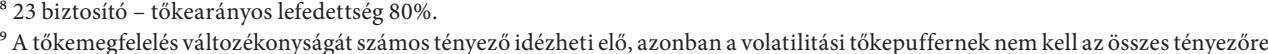
reflektálni, mert egyes esetekben, például ha az állomány jelentősen, illetve az előzetes várakozásoktól eltérően változik, vagya belső eljárásain, kalkulációs modelljein úgy változtat, ami a tőkemegfelelését szignifikánsan érintheti, elvárható, hogy a biztositó soron kívül meghatározza es bemutassa a tökehelyzetét.

${ }^{10}$ Ưn. vastag farku eloszlasok, illetve jobbra ferde eloszlások.

"Mely alapján a felügyelet kötelezheti a biztositót a tőkeszükségletének újraszámolására, illetve megfelelő nagyságú szavatoló tőke képzésére, ha megalapozottan feltetelezhetỏ, hogy a biztositó kockázati profilja megváltozot

${ }^{2} \mathrm{Az}$ (1) egyenletnek csak akkor van minden a-ra megoldasa, ha az X valoszinusegi valtozo abszolút folytonos. Esetünkben ez feltehetö. ${ }^{13} \mathrm{Az}$ MCR egy viszonylag egyszerú képlet alapjan hatårozhato meg, de nem lehet nagyobb, mint az SCR 45\%-a (tehát kisebb, mint az SCR), de el kell erni egy tevékenységtôl függó abszolút padlót, pl. életbiztositóknál 3,7 millió eurót (azaz kisbiztositók esetén ez az alsó padló lehet nagyobb az SCR-nél .

biztositó állományától, müködésétől, hanem a környezettől is fügs.

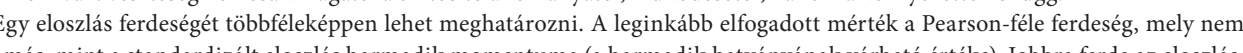
mán

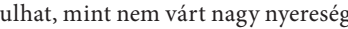

Intuitive az Y veszteség eloszlása vastagabb farkú az X eloszláśńńl, ha Y esetében a nagyon nagy károk nagyobb valószínüséggel fordulnak elő, mint az X esetében, és ez a reláció fokozódik az egyre nagyobb károkn
${ }^{17}$ Itt értelemszerüen csak a c $>0$ eset jöhet szóba, hiszen c $<0$ esetén a veszteségbő́l nyereség lesz, és fordítva.

${ }^{8} \mathrm{Az} \mathrm{Y}=\mathrm{aX}+\mathrm{b}$ lineáris transzformált eloszlásfüggvénye $g(x)=2 \varphi\left(\frac{x-g}{a}\right) \phi\left(\alpha\left(\frac{x-a}{a}\right)\right.$ Ezek alkotják a teljes ferde normális eloszláscsaládot. A volatilitási tơkepuffer mértéke azonban invariáns a lineáris transzformációra, ezért elég a standardizált verziót vizsgáln. ${ }^{19}$ bövebben ld. Azzalinil - azzalini.stat.unipd.it

${ }^{21}$ "Azzelinini2 - azzalini.stat.unipd.it alapján

${ }^{22} \sigma=2$ esetén már oly mértékben dől a sürűségfüggvény, hogy már a 80\%-os kvantilis is kisebb a várható értéknél, ami miatt vtpa $<0$. Negatív VTP akkor adódik, ha $2 \Phi^{-1}(99,5 \%)>\sigma>2 \Phi^{-1}(\alpha)$

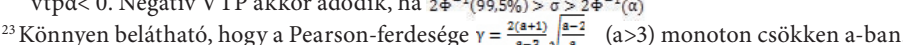
${ }^{24}$ Ez utóbbit nem nehéz belátni.

${ }^{25} \Gamma(p)=\int^{\dagger t^{-1}-e^{-1} d t a}$ faktoriális függvény kiterjesztése: $\Gamma(\mathrm{n})=(\mathrm{n}-1) !$ ! ha n nemnegatív egész szám.

${ }^{26} \mathrm{~A}$ p növelése az alábbi értelemben vékonyitja az eloszlás farkát: $X$ eloszlása vastagabb farkú, mint az Y eloszlása, ha a standardizáltjuk $\mathrm{f}(\mathrm{x})$ és $\mathrm{g}(\mathrm{x})$ sürüségfüggvényeire teljesül, hogy $\lim \frac{\mathrm{fBK}}{\frac{\mathrm{K}}{\mathrm{K}}=\infty} \mathrm{x}$.

${ }^{27}$ Valószínüségi változók összegének eloszlása az egyes eloszlások konvolúciója.

${ }^{28} \mathrm{AzX}$ valószinnüségi valtozo standardizaltja az X olyan lineáris transzformáltja, aminek várható értéke nulla, szórása

1: $\mathrm{X}^{\prime}=(\mathrm{X}-\mathrm{E}(\mathrm{X}) / \mathrm{D}(\mathrm{X})$, ahol $\mathrm{E}(\mathrm{X})$ a várható érték, $\mathrm{D}(\mathrm{X})$ a szórás, fetteve, hogy ezek léteznek.

nincs bizonyitva.

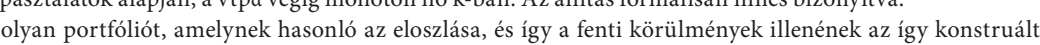

31 $A$ zat $f(x)$ datt terïl, ese 